\title{
A Framework For MIS Student Outcome Assessment And Program Review
}

Joseph T. Harder (Email: bssharde@befac.indstate.edu), Indiana State University Jeffrey S. Harper (Email: JeffHarper@indstate.edu), Indiana State University

\section{Introduction}

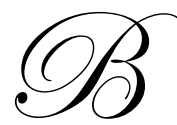

usiness schools and programs are under increasing pressure from accrediting bodies to develop and implement a cohesive, documented, and theoretically sound method for assessing student outcomes (Michlitsch and Sidle, 2002). For schools accredited by Association to Advance Collegiate Schools of Business, outcomes assessment and review is an integral component of the continuous improvement standard (AACSB, 2003). This paper outlines the development of a systematic and practical methodology for assessing program effectiveness and monitoring student development in the undergraduate MIS program. The model is a result of multiple needs identified during curriculum revitalization sessions and is responsive to additional issues relating to program assessment review, institutional effectiveness, and a student electronic portfolio project.

Expectations of IS Graduates - The Need to Respond to Change. Academics and industry practitioners have recognized that an "Expectation Gap" exists between the preparation of students upon completion of undergraduate MIS programs and the demands placed on them in career-track positions (Trauth, Farwell, and Lee, 1993). Several studies have attempted to define a set of requisite competencies for entering career-track positions in the IS industry. Some produce a content-oriented curriculum guide (Maier and Gambill, 1996, Davis, et al, 2002) while others focus on meta-competencies such as communication and integration skills (Yen, Lee, and Koh, 2001).

Our research agenda was to develop a model for ongoing individual student outcomes assessment and program curricular review. The following sections of this paper present a discussion of the needs of the academic, business, and student constituencies for an effective model for student outcome assessment, a description of the development and design of the framework, and practical guidelines for its implementation. We conclude by discussing the implications for curricula in higher education with regard to administration research and practice.

Traditional Outcomes Assessment. Historically, outcomes assessment in the MIS program at our university has been accomplished by conducting interviews with graduating seniors, recent alumnae, and employers of recent alumnae. Additionally, an advisory board comprised of industry practitioners provides a semi-annual review of the MIS program. While these efforts have yielded valuable input, they are, by nature, post hoc approaches to measuring the effectiveness of curriculum and delivery. Additionally, these inputs lack formal structure and are often subjective. With the rapidly changing content of the field, such an approach is less than optimal for maintaining currency of curriculum and assessing student preparation. The demands of changing technology are complicated by the traditionally minor role of curriculum development in rewarding faculty in higher education (Trauth, Farwell, and Lee, 1993).

In our program, efforts have been ongoing for the past three years to implement a more timely and methodical approach for measuring student outcomes and the adequacy of their preparation for the job market. One initiative was to develop and administer a web-based survey for employers and alumnae to use instead of paper surveys. More input is has been gathered as a result of this effort, but the nature and usability of the data has not changed. Based on the MIS faculty's collective desire for improvement and a perceived need to respond to ongoing university initiatives, a team of faculty from the MIS program began working toward creation of a practical and

Readers with comments or questions are encouraged to contact the authors via email. 
sound model for student development that can measure students' progress toward demonstrating their ability to employ the competencies and skills that are necessary to succeed as IS professionals.

The Portfolio Project - Documentation and Reflection. In 1999, our institution began exploring the feasibility of a campus-wide electronic portfolio system for documenting and supporting student development. Such initiatives have met with some success at other institutions (Cambridge, et al, 2001). At least one institution has built its entire student assessment system around an E-Portfolio, and no longer issues grades (Doherty, Riordan, and Roth, 2002). In this case, the E-Portfolio was a technological update of a long-held view of broad competency development as the appropriate measure of educational outcomes (Earley, Mentkowski, and Schaefer, 1980).

Our electronic portfolio initiative necessitated identification of student competencies, attainment of which could then be documented reflectively by the students and their instructors. Some competencies were non programspecific, and thus suitable for inclusion in all student portfolios campus-wide. The portfolio template also left open the possibility of school, program, and even individual student-level competencies that would collectively define the preparedness of graduating students. Once competencies have been defined, students and faculty work together to provide input to document progress toward competency achievement. Such input can be in multiple media formats, providing a rich channel for communicating and reflecting on learning. An example of a competency based portfolio is shown in Appendix A.

\section{Developmental Design: Competency Clusters And Development Phases}

Implementation of an E-Portfolio template provided an opportunity to identify program-level competencies for MIS majors. Program-centered competency clusters are not new in business disciplines. The AICPA has established nationally recognized competencies for Certified Public Accountants (Briggs, 2002).

Competency Clusters. Our assessment model is built on the concept of four core competency clusters. We developed these competency clusters from the literature describing valid research into the kinds of knowledge and skills that are known to be necessary for success as a practitioner in the MIS field. Each of these clusters: Technical, Analytical, Communicative, and Managerial, consists of a set of tangible abilities that can be measured. The four competency clusters and their corresponding operational definitions are presented in Table 1.

Table 1: Competency Clusters in Student Outcomes Assessment

\begin{tabular}{|l|l|}
\hline Competency Cluster & Operational Definition \\
\hline Technical & $\begin{array}{l}\text { An understanding of the mechanics of information technology and the importance } \\
\text { of system performance in achieving organizational goals and the ability to } \\
\text { appropriately use information technology tools. }\end{array}$ \\
\hline Analytical & $\begin{array}{l}\text { The ability to identify and define organizational problems and propose reasonable } \\
\text { solutions. This includes problem framing and boundary issues as well as logical } \\
\text { cause and effect. }\end{array}$ \\
\hline Communicative & $\begin{array}{l}\text { The ability to communicate orally and in writing cogently and succinctly. This } \\
\text { includes the ability to describe a problem in business terms and to structure } \\
\text { communications in an acceptable business format. }\end{array}$ \\
\hline Managerial & $\begin{array}{l}\text { The ability to coordinate and direct the efforts of others toward an organizational } \\
\text { goal. This includes the ability to identify, state and execute goal directed plans. }\end{array}$ \\
\hline
\end{tabular}

Identifying core competencies relating to academic programs, careers, and life paths is not a new idea (Evers, Rush, and Berdrow, 1998). In the specific arena of academics, many efforts have been made to identify such competencies and build curricula around them (Briggs, 2002; Mikolaj and Baker, 2001). The four "Competency 
Clusters" we have identified are grounded in these prior works and others, from both content and methodology perspectives.

The necessity of technical competence as a core program outcome is supported by many prior works investigating critical success factors for the IS professional. As MIS is considered a highly technical field, a naïve approach to outcomes assessment might include only this competency. Several researchers have studied the effectiveness of MIS programs in preparing students for professional positions in the industry (Davis, et al, 2002; Maier and Gambill, 1996). As expected, technical ability such as programming skills and the ability to appropriately use information technology tools were strongly represented in both the actual (Maier and Gambill) and desired (Davis, et al) skill sets.

The necessity for IS professionals to be able to demonstrate analytical competency is consistent with Trauth, Farwell, and Lee's (1995) observation that "analyzing business problems and finding effective IS solutions will hence become the single most important activity for IS in the future." A related construct that is frequently found in lists of desired learning outcomes is critical thinking. We subsume this characteristic into the analytical competency. Critical thinking is generally described as requiring students to "... not only master the information, but also develop an understanding of the discipline, enough to think about (and question) the information" (McEwen, 1994). Students who steadily progress in analytical ability will emerge from the program able to adapt existing knowledge to new and challenging situations.

The communication competency is supported by Yen, Lee, and Koh (2001) in their placement of interpersonal and organizational knowledge (among others) on a list of four critical IS skills. Parasuraman, Zeinthaml, and Berry (1985) include communication as a critical foundational skill in their general model of service quality (SERVQUAL), which has been cited in the quality research of many disciplines, including IS (Carr, 2002). Rational persuasion and personal appeal are communication skills that were identified by Enns, Huff, and Higgins (2003) as critical to CIO's ability to influence top managers.

Managerial competency, as we use it in this framework, has the broadest definition. Other competency maps assign several constructs to cover this range of behaviors. For example, Willcocks and Sykes (2000) identify IT leadership, business systems thinking, architecture planning, and relationship building, among others, as “...key in-house IT capabilities." Although leadership is often identified as a separate individual competency (Briggs, 2002), we subsume it in the managerial competency. A more specific "management of IT" competency is identified by Bassellier, Reich, and Benbasat (2001) as a critical component of business managers' IT competence. Components of this construct can be found in each of the technical and managerial competencies, depending on the nature of the component.

The competency clusters developed for our model were tested for acceptance using four groups. The MIS program Advisory Board, faculty, and students, as well as a group of MIS academics used as external reviewers, were polled for agreement with the four competencies as a complete framework for required skills and abilities for the IS professional. Each of the four groups positively endorsed the competency clusters as defined.

Developmental Stages. Student learning within each of these competency clusters can form a basis for a measurable continuum along which individuals progress. We believe that as students progress through the MIS program, they should achieve higher levels of competency within each of these areas. In other words, we expect that a senior-level student will be able to demonstrate higher competency in each area than when he or she was a sophomore.

Measurement of a student's achievements using these competency clusters yields considerable insight into how well prepared a student is for employment. When the achievements of all students are considered, insight can be gained into how well the curriculum is facilitating intellectual growth and actual ability. Therefore, students' progress on these competencies can, collectively, form a measure of the effectiveness of the design and execution of the degree program curriculum. Implicit to the idea of student outcomes assessment is the thought that measurement of student progress must be based upon something more robust than simple completion of the program elements (i.e. 
required classes). In order for valid program assessment to be possible, the assessment must determine the degree to which learning activities lead to students' ability to demonstrate and apply appropriate skills.

A student's ability to simply complete the degree program may be indicative of some minimum standard. However, degree completion does not indicate the unique level to which each student is prepared for entry into the IS field or which of an individual's talents is either exceptional or in need of improvement. Even the student transcript falls short of providing a comprehensive review of competencies, since all courses require demonstration of multiple competencies. Nor does the transcript provide documentation of the specific abilities demonstrated by the student during the learning experience (what can they $d o$ ?). Thus, employers typically rely on oral interviews and "faith" in a program to determine the abilities of a prospective employee/graduate.

Progress in each of the four competency clusters defined above can be measured. We have identified five developmental stages that are appropriate to describing the level of learning achieved by students as they move toward completion of the curriculum. In effect, we expect students to move from the lowest-level stages (user, problem identifier) to the highest-level (solution implementer) stage in each of the four competencies by the time they graduate. Each developmental stage and an operational definition of the stage is listed in Table 2.

Table 2: Developmental Stages in Student Outcomes Assessment

\begin{tabular}{|l|l|}
\hline Developmental Stage & Operational Definition \\
\hline User & $\begin{array}{l}\text { The expected incoming competency level of students in our program. } \\
\text { Competency building needed to reach this developmental stage will be considered } \\
\text { remedial }\end{array}$ \\
\hline Problem Identifier & $\begin{array}{l}\text { Well versed in basic business skills, this individual is able to identify } \\
\text { organizational problems (particularly information-based problems) and to state } \\
\text { them using business terminology. }\end{array}$ \\
\hline Problem Solver & $\begin{array}{l}\text { Able to form potential solutions to organizational problems (particularly } \\
\text { information-based problems) and select the most appropriate one based on } \\
\text { organizational impact and feasibility. }\end{array}$ \\
\hline Solution Implementer & $\begin{array}{l}\text { Able to manage the efforts of others to plan and execute solutions to } \\
\text { organizational problems. Able to cope with unexpected complications within a } \\
\text { framework of priorities and constraints. }\end{array}$ \\
\hline
\end{tabular}

The terminal stage of "Solution Implementer" is conceptually consistent with prior work in student preparedness for IS careers. Trauth, Farwell, and Lee (1993), for example, propose the term "Integrator" to identify someone who can "... carry out enterprise-wide tasks". Business Process Reengineering (Hammer and Champy, 1993) is one such global task. Smaczny (2001) expands somewhat on the idea of Solution Implementer in his "Fusion" construct. An IT manager achieves fusion when IT strategies are not only successfully implemented, but implemented in concert with the organization's strategic objectives.

A half-century old taxonomy of learning objectives is still widely cited in current assessment literature. Bloom, et al (1956) proposed that the following educational outcomes adequately described the process of effective learning: Knowledge, Comprehension, Application, Analysis, Synthesis, and Evaluation. In order to more effectively utilize Bloom's taxonomy in curricular studies, Krathwohl (2002) has re-formulated it into two parallel taxonomies - knowledge and cognitive process. The cognitive process dimension is a close parallel to our stage model of professional development.

Krathwohl's (2000) cognitive processes are: Remember, understand, apply, analyze, evaluate, and create. These processes map to our learning stages is presented in Figure 1. 
The user level in our learning stage model denotes readiness to begin the process of professional development within our program. Mapping only the highest three levels of development to Krathwohl's adaptation of Bloom's taxonomy reflects this positioning. Remembering and understanding are consistent with the operational definition of a Problem Identifier in Table 2. To complete this stage, we expect students to remember and understand basic business principles, so that the business implications will be recognized in the practical case problems they will encounter in lower level MIS courses.

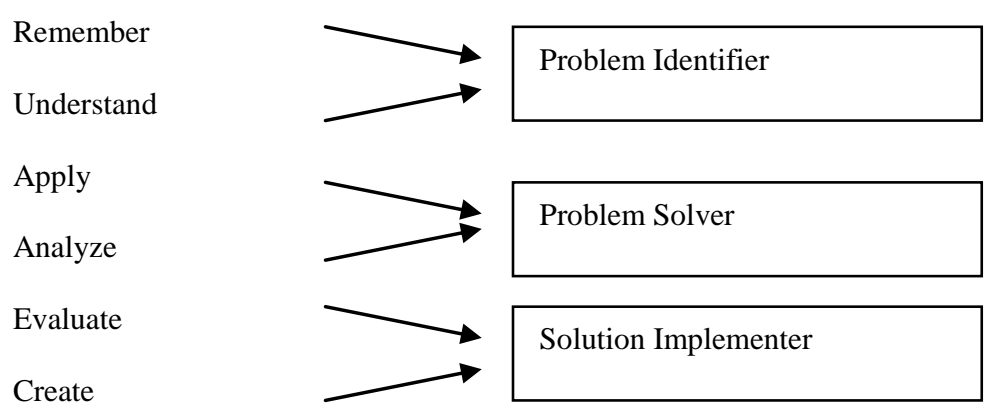

Figure 1: Cognitive Processes and Developmental Stages

Students that have attained the problem solver developmental stage have demonstrated the ability to 'form potential solutions' [apply] and 'select the most appropriate one based on organizational impact and feasibility [analyze]. Finally, students that have attained the solution implementer developmental stage can 'plan and execute solutions' [create] and 'cope with unexpected complications within a framework of priorities and constraints [evaluate]. Bloom's original taxonomy (1956) as revised by Krathwohl (2002) serves very well as a foundational construct for our hierarchy of developmental stages.

\section{Putting Theory Into Practice: Demonstrated Abilities And Key Learning Activities}

Measurement of a student's development within each of the four competencies described above can be achieved by determination of what they can $d o$. A widely accepted model of experience and learning is proposed by Kolb (1978). He posits that learning is most effectively facilitated and measured by iteratively offering learners new experiences, the opportunity to reflect, and a mandate to use their derived conceptions to interpret/solve new problems. To this end, we have identified demonstrated abilities (DAs) that are appropriate to each competency and developmental phase. Simply stated, demonstrated abilities are tangible, documented results of students' work in practical exercises or activities. These demonstrated abilities may or may not result from a classroom exercise; several result from co- or extra-curricular activities.

Demonstrated Abilities. The concept of how demonstrated abilities related to each competency and developmental phase is shown in Figure 2, the Student Outcomes Assessment Matrix. Demonstrated abilities are associated with the intersection of a developmental stage and a competency, rather like a field in a database table that represents the intersection of an attribute and a tuple. 
DEVELOPMENTAL STAGES

\begin{tabular}{|c|c|c|c|c|c|}
\hline $\begin{array}{l}\mathbf{C} \\
\mathbf{O}\end{array}$ & & Technical & Analytical & Communicative & Managerial \\
\hline $\begin{array}{l}\mathbf{M} \\
\mathbf{P} \\
\mathbf{E} \\
\mathbf{T}\end{array}$ & USER & & & & \\
\hline $\begin{array}{l}\mathbf{E} \\
\mathbf{N} \\
\mathbf{C} \\
\mathbf{Y}\end{array}$ & $\begin{array}{l}\text { PROBLEM } \\
\text { IDENTIFIER }\end{array}$ & & \multicolumn{2}{|c|}{$\begin{array}{c}\text { DEMONSTRATED } \\
\text { ABILITIES } \\
\end{array}$} & \\
\hline $\begin{array}{l}\mathbf{C} \\
\mathbf{L}\end{array}$ & $\begin{array}{l}\text { PROBLEM } \\
\text { SOLVER }\end{array}$ & & & & \\
\hline $\begin{array}{l}\mathbf{U} \\
\mathbf{S} \\
\mathbf{T} \\
\mathbf{E}\end{array}$ & \begin{tabular}{|l|} 
SOLUTION \\
IMPLEMENT
\end{tabular} & TER & & & \\
\hline
\end{tabular}

Figure 2: The Student Outcomes Assessment Matrix

Appendix A lists the DAs we have developed for every combination of developmental stage and competency cluster. In operationalizing our student outcomes assessment model, demonstrated abilities are assigned points that accumulate as more DAs are completed. The points are then used to determine whether a student has completed a developmental phase in a given core competency.

Key Learning Activities. Key learning activities (KLAs) are the actions that a student undertakes which, when successfully completed, result in a demonstrated ability. KLAs may be classroom based or they may be associated with organizations or events outside of the classroom. In our program curriculum, each class has a set of three to five KLAs that are appropriate to the topics within the course and lead to specific demonstrated abilities. For example, in the systems analysis class, a key learning activity might be a case study that requires the student to develop a set of data-flow diagrams. Successful completion of this assignment allows the student to demonstrate the ability to develop a data-flow diagram, given certain information - a demonstrated ability within the analytical competency cluster.

Successful completion of a key learning activity will allow a student to clearly document that he or she has demonstrated the skill to do one or more of the demonstrated abilities listed in Figure 3. Instructors have identified KLAs for each required MIS course in our curriculum.

This approach allows for assessment by observing process, outcomes, or both during the term (Michlitsch and Sidle, 2002). A standardized web form is used to define, justify, and establish metrics for KLAs for each course. Once identified, the KLAs are included in the Master Course Outline that is approved by the faculty and serves as a template for instructor syllabi. A minimum grade for each KLA is required in order to receive credit (points) for the demonstrated abilities associated with the KLA. The minimum grade varies with the KLA and is determined by the instructor.

Record Keeping. While it is each student's responsibility to manage his or her own portfolio, including outcomes assessment, the MIS program has developed a web-enabled database for data entry and tracking. At the end of each semester, each faculty member enters the grade of each student on each KLA. The database 
automatically calculates the points earned on each demonstrated ability and totals the points the student has earned within the appropriate competency/developmental phase cell.

Each student is able to print a report showing his or her demonstrated abilities and his or her status in each competency cluster. Once a student has earned a predetermined number of points associated with a particular developmental level in a particular competency, he or she is said to possess a particular level of development within the competency. For example, when a student has earned the predetermined number of points in the cell associated with the Problem Solver developmental level for the Analytical competency, the student is considered an Analytical Problem Solver. The goal of the program is to have each student obtain the points necessary to be a Solution Implementer in each of the four core competency areas. Students who obtain the points necessary to be a Solution Implementer in each of the four core competency areas graduate "with distinction" from the MIS program.

Curricular Development. Although this project was originally intended to provide a structured, formalized means for assessing student outcomes, a complimentary by-product was quickly identified. In addition to providing students a way to document their demonstrated abilities, this model allows for curricular review. Gap analysis can show deficiencies in the curriculum based upon the students' cumulative abilities to demonstrate competence. For example, if analysis indicates that most students are not demonstrating communicative skills at the Solution Implementer level, the curriculum can be adjusted to provide more emphasis on oral and written communication appropriate to that developmental level. Detecting "developmental gaps" during the university experience will help avoid "expectation gaps" (Trauth, Farwell and Lee, 1993) upon entry into the workforce.

\section{Summary And Conclusions}

A stage model for student outcomes assessment has been presented in this paper. The model is based upon student development along four competency clusters that MIS research has recognized as important to be a successful MIS practitioner. Progress in developing these competencies is measured by what students can do (demonstrated abilities) as they move to higher developmental phases. Key learning activities provide the opportunity for students to demonstrate and document these abilities.

The model is intended to be a practical means of determining students' preparation for entry into the workforce that is justified through what is formally known about industry needs in IS professionals and student learning. The model can measure progress of individual students and serve as a proxy for the effectiveness of the MIS program. Aggregate results can be used for ongoing program assessment and review. Additionally, data can be used by academic advisors in the guidance of their advisees into certain coursework or specialties. Documentation resulting from this approach can also be helpful in clearly presenting assessment efforts to external accrediting bodies.

Our work has been developmental in nature. As such, we expect that refinements and modifications will be necessary over time as more is learned about effective assessment and as our field continues to change. This is especially true for the demonstrated abilities presented in Appendix A. The model is not proposed as an "end-all" to student outcomes assessment and curricular review; instead, we envision this as an additional, formal and structured tool to assist in an important and meaningful process.

\section{References}

1. AACSB International, Eligibility Standards and Procedures for Business Accreditation, April 25, 2003.

2. Bloom, B.S., Hastings, J.T., \& Madaus, G.F. (1971), Handbook on formative and summative evaluation of student learning, McGraw Hill, New York, NY.

3. Briggs, K., "Competencies, the Differential” (2002), Journal of Accountancy, (4:3), pp. 79-80.

4. $\quad$ Cambridge, B., Kahn, S., Tompkins, D.P., \& Yancey, K.B. (eds.) (2001), Electronic Portfolios: Emerging Practices in Student, Faculty, and Institutional Learning, American Association for Higher Education, Washington, DC. 
5. Carr, Christopher, "A psychometric evaluation of the expectations, perceptions, and difference-scores generated by the IS-adapted SERVQUAL instrument” (2002), Decision Sciences, (33:2), , pp. 281-296.

6. Davis, G.B., Feinstein, D., Gorgone, J.T., Longenecker, Jr., H. E., \& Valacich, J.S. (2002), "IS 2002: An Update of the Information Systems Model Curriculum", Proceedings of the Sixteenth Annual Conference of the International Academy for Information Management, New Orleans, LA, pp. 76-82.

7. Doherty, A., Riordan T., \& Roth, J. (2002), Student Learning: A Central Focus for Institutions of Higher Education, Alverno College Institute, Milwaukee, WI.

8. Earley, M., Mentkowski, M., \& Schaefer, J. (1980), Valuing at Alverno: The Valuing Process in Liberal Education, Alverno Press, Milwaukee, WI.

9. Enns, H.G., Huff, S., Higgins, C.A (2003), "CIO Lateral Influence Behaviors: Gaining Peers' Commitment to Strategic Information Systems,” MIS Quarterly, (27:1), March, pp. 155-176.

10. Evers, F.T., Rush, J.C., \& Berdrow, I. (1998), The Bases of Competence: Skills for Lifelong Learning and Employability, Jossey-Bass.

11. Hammer, M., and Champy, J. (1994), Reengineering the Corporation: A Manifesto for the Business Revolution, Harper Business, New York, NY.

12. Kolb, D.A., 197(???), Experiential Learning: Experience as the Source of Learning and Development, Prentice Hall, Englewood Cliffs, NJ.

13. Krathwohl, D.R. (2002), "A Revision of Bloom's Taxonomy: An Overview", Theory Into Practice”, (41:4), pp. 212-220.

14. Lee, D.M., Trauth, E.M., \& Farwell, D. (1995), "Critical Skills and Knowledge Requirements of IS Professionals,: A Joint Academic / Industry Investigation”, MIS Quarterly, (19:3), pp. 313-337.

15. Maier, J.L., \& Gambill, S. (1996) "CIS/MIS Curriculums in AACSB-Accredited Colleges of Business", Journal of Education for Business, (71:6), August, pp. 329-333.

16. McEwen, B.C. (1994), "Teaching Critical Thinking Skills in Education", Journal of Education for Business, (70:2), pp. 99-106.

17. Mikolaj, P., and Hamilton, K., (2003) "Building Desired Competencies in Risk Management and Insurance Students," Unpublished Working Paper, Indiana State University.

18. Michlitsch J.F, \& Sidle, M.W. (2002), "Assessing student learning outcomes: A comparative study of techniques used in business school disciplines", Journal of Education for Business (77:3), pp. 125-130.

19. Myers, B., Kappelman, L., \& Prybutok, V. (1997), “A Comprehensive Model for Assessing the Quality and Productivity of the Information Systems Function: Toward a Theory for Information Systems Assessment", Information Resources Management Journal (10:1), pp. 6-19.

20. Parasuraman, A, Zeithaml, V.A., \& Berry, L.L. (1985), "A conceptual model of service quality and its implications for future research", Journal of Marketing, (49), Fall, pp. 41-50.

21. Smaczny, T., "Is an alignment between business and information technology the appropriate paradigm to manage IT in today's organizations?" Management Decision, (39:10), pp. 797-802.

22. Trauth, E.M., Farwell, D.W., \& Lee, D. (1993), "The IS Expectation Gap: Industry Expectations Versus Academic Preparation", MIS Quarterly, (17:3), pp. 293-302.

23. Willcocks, L., \& Sykes, R. (2000), The Role of the CIO and IT Function in ERP, Communications of the ACM (43:4), pp. 32-38.

24. Yen, D.C., Lee, S., \& Koh, S. (2001), "Critical Knowledge / Skill Sets Required by Industries: An Empirical Analysis”, Industrial Management + Data Systems, (101:8/9), pp 432-442. 


\section{APPENDIX A: \\ THE STUDENT OUTCOMES ASSESSMENT MATRIX}

\section{DEVELOPMENTAL STAGES}

\begin{tabular}{|c|c|c|c|c|}
\hline & Technical & Analytical & Communicative & Managerial \\
\hline User & $\begin{array}{l}\text { TU1 - Possesses a } \\
\text { basic understand-ing } \\
\text { of the role and use of } \\
\text { computer-based } \\
\text { information systems } \\
\text { in an organizational } \\
\text { context } \\
\text { TU2 - Demon-strates } \\
\text { basic literacy of the } \\
\text { functions of } \\
\text { information } \\
\text { technology devices } \\
\text { and infrastructure } \\
\text { TU3 - Uses personal } \\
\text { productivity software } \\
\text { effectively }\end{array}$ & $\begin{array}{l}\text { AU1 - Separates } \\
\text { cause and effect and } \\
\text { understands } \\
\text { relationships in a } \\
\text { simple business } \\
\text { scenario } \\
\text { AU2 - Understands } \\
\text { the logic and } \\
\text { completeness of an } \\
\text { analysis provided by } \\
\text { another person }\end{array}$ & $\begin{array}{l}\text { CU1 - Can } \\
\text { understand a clearly } \\
\text { written report } \\
\text { CU2 - Is able to } \\
\text { identify important } \\
\text { components of an } \\
\text { oral presentation } \\
\text { CU3 - Participates in } \\
\text { group discussion } \\
\text { CU4 - Can identify } \\
\text { important listening } \\
\text { skills }\end{array}$ & $\begin{array}{l}\text { MU1 - Able to } \\
\text { understand stated } \\
\text { project goals } \\
\text { MU2- Understands } \\
\text { project mgmt. } \\
\text { concepts and } \\
\text { purposes } \\
\text { MU3 - Can } \\
\text { understand an } \\
\text { existing project plan }\end{array}$ \\
\hline $\begin{array}{l}\text { Problem } \\
\text { Identifier }\end{array}$ & $\begin{array}{l}\text { TPI1 - Understands } \\
\text { programming } \\
\text { structures and } \\
\text { techniques } \\
\text { TPI2 - Demon-strates } \\
\text { familiarity with } \\
\text { programming tools } \\
\text { and their appropriate } \\
\text { use TPI3 - Uses } \\
\text { computer-based } \\
\text { information tools in } \\
\text { effective } \\
\text { communication with } \\
\text { others } \\
\text { TPI4 - Uses } \\
\text { computer-based } \\
\text { information systems } \\
\text { as an effective } \\
\text { research tool }\end{array}$ & $\begin{array}{l}\text { API1 - Evaluates an } \\
\text { information-based } \\
\text { problem in terms of } \\
\text { technical, } \\
\text { operational, and } \\
\text { economic feasibility } \\
\text { API2 - Determines } \\
\text { the relevance of facts } \\
\text { associated with an } \\
\text { information-based } \\
\text { problem } \\
\text { API3- Understands } \\
\text { and uses the } \\
\text { analytical tools used } \\
\text { in solving } \\
\text { information-based } \\
\text { problems }\end{array}$ & $\begin{array}{l}\text { CPI1 - Submits short, } \\
\text { effective reports on } \\
\text { specific assigned } \\
\text { topics } \\
\text { CPI2 - Can give a } \\
\text { short, effective } \\
\text { original presentation } \\
\text { on an assigned topic } \\
\text { CPI3 - Asks relevant } \\
\text { questions in group } \\
\text { discussions } \\
\text { CPI4 - Can perceive } \\
\text { and restate what } \\
\text { others have presented }\end{array}$ & $\begin{array}{l}\text { MPI1 - Define } \\
\text { boundaries of an } \\
\text { information-based } \\
\text { problem } \\
\text { MPI2 - Works } \\
\text { effectively in a team } \\
\text { environment } \\
\text { MPI3 - Defines an } \\
\text { information-based } \\
\text { problem using } \\
\text { business terms and } \\
\text { concepts }\end{array}$ \\
\hline $\begin{array}{l}\text { Problem } \\
\text { Solver }\end{array}$ & $\begin{array}{l}\text { TPS1 - Selects and } \\
\text { applies appropriate } \\
\text { programming } \\
\text { structures and } \\
\text { techniques based } \\
\text { upon a specific } \\
\text { problem context } \\
\text { TPS2 - Designs a } \\
\text { simple program from } \\
\text { a basic specification } \\
\text { TPS3 - Uses } \\
\text { specialized software } \\
\text { to represent business } \\
\text { processes and } \\
\text { information flows } \\
\text { (logical models) }\end{array}$ & $\begin{array}{l}\text { APS1 - Able to } \\
\text { optimize key } \\
\text { business variables in } \\
\text { solution design while } \\
\text { meeting stated } \\
\text { constraints } \\
\text { APS2 - Uses } \\
\text { appropriate analytical } \\
\text { tools to effectively } \\
\text { evaluate solution } \\
\text { alternatives to an } \\
\text { information-based } \\
\text { problem } \\
\text { APS3 - Is able to } \\
\text { develop a logical } \\
\text { model based upon } \\
\text { stated user } \\
\text { requirements }\end{array}$ & $\begin{array}{l}\text { CPS1 - Identifies and } \\
\text { reports on } \\
\text { appropriate topic } \\
\text { within a project } \\
\text { context } \\
\text { CPS2 - Gives an oral } \\
\text { presentation on a } \\
\text { topic of choice } \\
\text { CPS3 - Participates } \\
\text { in discussions that } \\
\text { resolve conflicts and } \\
\text { result in achieving } \\
\text { team goals } \\
\text { CPS4 - Asks relevant } \\
\text { questions to resolve } \\
\text { uncertainties in a } \\
\text { project context }\end{array}$ & $\begin{array}{l}\text { MPS1-Develop } \\
\text { project goals and } \\
\text { objectives for an } \\
\text { information-based } \\
\text { problem } \\
\text { MPS2-Able to take } \\
\text { primary } \\
\text { responsibility for } \\
\text { accomplishment of a } \\
\text { specific project task } \\
\text { or component } \\
\text { MPS3-Identifies the } \\
\text { steps, sequencing, } \\
\text { and resources needed } \\
\text { to complete an } \\
\text { information project }\end{array}$ \\
\hline
\end{tabular}




\begin{tabular}{|c|c|c|c|c|}
\hline & & $\begin{array}{l}\text { APS4 - Develops } \\
\text { appropriate } \\
\text { contingency plans } \\
\text { based upon the } \\
\text { potential interaction } \\
\text { between the project } \\
\text { solution and external } \\
\text { systems }\end{array}$ & & \\
\hline $\begin{array}{l}\text { Solution } \\
\text { Implementer }\end{array}$ & $\begin{array}{l}\text { TSI1 - Designs the } \\
\text { specifications for a } \\
\text { program which } \\
\text { conforms to stated } \\
\text { user requirements } \\
\text { TSI2 - Can perceive } \\
\text { the limitations of } \\
\text { application } \\
\text { development tools } \\
\text { and select the most } \\
\text { appropriate tool(s) in } \\
\text { a given context } \\
\text { TSI3 - Develops the } \\
\text { program(s) for an } \\
\text { information-based } \\
\text { solution that satisfies } \\
\text { user needs } \\
\text { TSI4 - Demon- } \\
\text { strates an } \\
\text { understanding of the } \\
\text { technical aspects of } \\
\text { system } \\
\text { administration } \\
\text { TSI5 - Completes } \\
\text { technical coursework } \\
\text { or practical } \\
\text { experience outside } \\
\text { the MIS curriculum }\end{array}$ & $\begin{array}{l}\text { ASI1 - Uses } \\
\text { analytical tools } \\
\text { appropriately in } \\
\text { testing, monitoring, } \\
\text { and maintaining an } \\
\text { information-based } \\
\text { solution } \\
\text { ASI2 - Recognizes } \\
\text { when to execute } \\
\text { contingency plans } \\
\text { ASI3 - Responds } \\
\text { appropriately to } \\
\text { unexpected changes } \\
\text { in requirements } \\
\text { during } \\
\text { implementation or } \\
\text { testing of a system } \\
\text { with minimum } \\
\text { impact on project } \\
\text { goals } \\
\text { ASI4 - Able to detect } \\
\text { and evaluate levels of } \\
\text { user satisfaction and } \\
\text { other environmental } \\
\text { cues associated with } \\
\text { a delivered system } \\
\text { ASI5 - Completes } \\
\text { personal self- } \\
\text { assessment } \\
\text { preparatory to } \\
\text { entering the } \\
\text { employment market }\end{array}$ & $\begin{array}{l}\text { CSI1 - Submits } \\
\text { clearly written, } \\
\text { logically organized, } \\
\text { accurate reports that } \\
\text { can be understood by } \\
\text { a target audience } \\
\text { CSI2 - Makes a } \\
\text { poised and polished } \\
\text { extemporaneous } \\
\text { presentation that can } \\
\text { be understood by the } \\
\text { target audience } \\
\text { CSI3 - Moderates } \\
\text { discussions that } \\
\text { resolve conflicts and } \\
\text { result in achieving } \\
\text { team goals } \\
\text { CSI4 - Effectively } \\
\text { presents project } \\
\text { goals, progress, and } \\
\text { results in the business } \\
\text { context } \\
\text { CSI5 - Delivers a } \\
\text { presentation or } \\
\text { significant report } \\
\text { within a co-curricular } \\
\text { organization or work } \\
\text { environment }\end{array}$ & $\begin{array}{l}\text { MSI1- Deliver a } \\
\text { solution to an } \\
\text { information-based } \\
\text { problem that achieves } \\
\text { stated goals } \\
\text { MPSI2-Manage a } \\
\text { team to successful } \\
\text { project completion } \\
\text { MSI3-Executes a } \\
\text { plan that delivers an } \\
\text { appropriate } \\
\text { information-based } \\
\text { solution } \\
\text { MSI4-Demonstrates } \\
\text { leadership qualities } \\
\text { through a significant } \\
\text { role (e.g. officer, } \\
\text { chairperson or } \\
\text { supervisor) in a co- } \\
\text { curricular } \\
\text { organization or work } \\
\text { environment }\end{array}$ \\
\hline
\end{tabular}

